OCCASIONAL PIECE

\title{
William Penny Brookes (1809-1895): forgotten Olympic Lord of the Rings
}

\section{H Ashrafian}

Br J Sports Med 2005;39:969. doi: 10.1136/bjsm.2005.019331

The contribution of Dr William Penny Brookes (18091895 ) to the Olympic Games is scarcely reported in the medical literature. Presented here is a brief report of his life and work. Furthermore, the need to promote public health and fitness through the Olympics is re-emphasised.

\section{Correspondence to: Dr Ashrafian, Great Ormond Street Hospital for Children, London WCIN 3JH, UK; ashrafian@ email.com}

Accepted 3 April 2005
$\mathrm{T}$ he recent enthusiasm for the Olympic Games has left me somewhat disheartened that the medical literature seldom if ever mentions a medical colleague who was instrumental in the evolution and inspiration of the modern Olympic movement.

William Penny Brookes (1809-1895) studied medicine at Guy's, St Thomas's, Sorbonne, and Padua (fig 1). Receiving his Membership to the Royal College of Surgeons of England (MRCS) and Licentiate of the Society of Apothecaries of London (LSA) in 1831, he became a dedicated local physician, considering the individual nature of his patients' needs as well as placing public health high on his agenda, tackling local sanitation and hygiene. Furthermore, he considered community matters important and contributed to issues such as education, transport, and botany while also becoming a magistrate in 1841. ${ }^{1}$ As he was much inspired by the ideal and conviction of the Ancient Olympic Games initiated by his classical schooling, he set about to revive a modern Olympic fellowship.

A Salopian based at the town of Much Wenlock, he founded the Wenlock Olympian society in 1850 in order to promote a "moral, physical and intellectual" movement that predates the "Citius, altius, fortius" philosophy. He had an Olympiad held that year and also continually requested the Greek establishment to hold a revived Olympic event. Eventually the philanthropist Evangelis Zappas (1800-1865) financed a new Athenian Olympic Games in 1859, and Brookes donated a stipend for the prize money. $^{2}$

Brookes introduced the Shropshire Olympic Games in 1861 and set up a National Olympian Association (NOA) based in Liverpool four years later. The following year he continued this with the United Kingdom's first national Olympic Games in 1866 set at London's Crystal Palace, and by repeating these games, he expanded on this concept by publicly proposing the benefits of an international Olympic event through the Greek press in 1881 .

In 1890 Brookes was visited by Baron Pierre Frédy de Coubertin (1863-1937), the celebrated

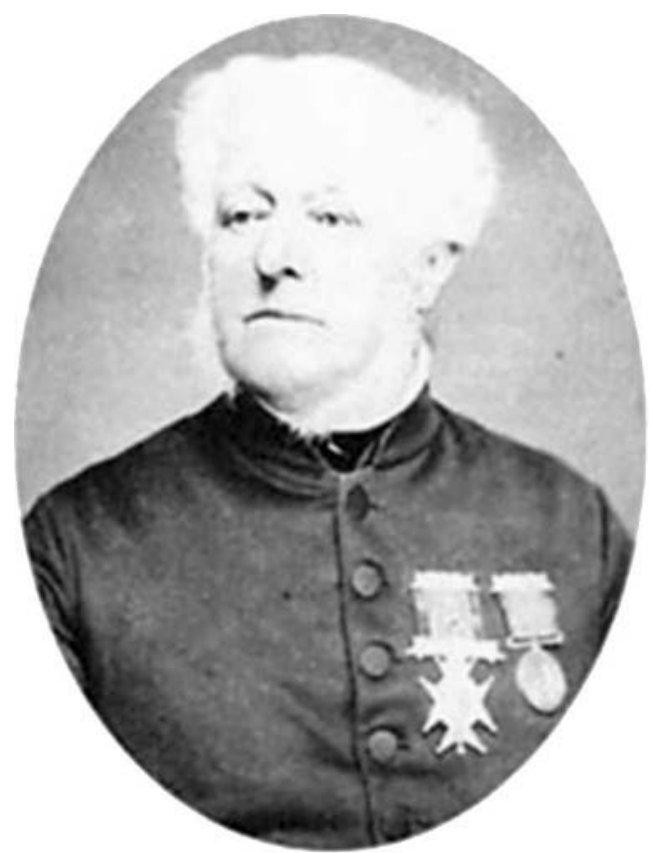

Figure 1 William Penny Brookes (1809-1895). Wenlock Olympian Society.

French educator who also dreamt of an international Olympic movement. Coubertin, who was witness to Brooks' Olympiad, ${ }^{3}$ organised an international Olympic congress at the Sorbonne in 1894 naming Brookes as an honorary member, who unfortunately was an absentee because of illness. The congress led to the creation of the International Olympic Committee, and progressed to the first modern Olympic Games based at Athens in 1896. Brookes himself passed away in 1895 and never had the opportunity to see his life's dream of the games become a reality.

If as colleagues we are to commemorate and respect the memory of William Penny Brookes, we will not only have to consider his significant contribution to the Games, but also to continue the important task of translating the magnificence of Olympic sport into promoting health and fitness for the public at large.

\section{REFERENCES}

1 Furbank M, Cromarty H, McDonald G. William Penny Brookes and the Olympic connection. Much Wenlock, Shropshire: Wenlock Olympian Society, 1996:1-11.

2 Young DC. The modern Olympics: a struggle for revival. Baltimore: Johns Hopkins University Press, 1996:4-135.

3 de Coubertin P. Les Jeux Olympiques à Much Wenlock. Rev Athlét 1890;1:705-13. 